\title{
The Pathophysiology of Antiphospholipid Syndrome
}

\author{
Pablo Ruiz Sada ${ }^{1}$, Hannah Cohen ${ }^{2}$ and David Isenberg ${ }^{*}, 3$ \\ ${ }^{I}$ Hospital Universitario de Basurto, Departamento de MedicinaInterna, Bilbao, Spain \\ ${ }^{2}$ University College London, London, UK \\ ${ }^{3}$ Centre for Rheumatology Research, Division of Medicine, University College London, London, UK
}

\begin{abstract}
Advances in our knowledge of the pathogenic mechanisms of antiphospholipid syndrome have been achieved in the past few years. Apart from the well-known role of anti- $\beta 2$-glycoprotein I antibodies, complement, endocrine and genetic factors and a variety of other molecules are now under investigation. These new approaches should lead to novel explanations and potential new treatment options.
\end{abstract}

Keywords: Anti- $\beta 2$-glycoprotein, antiphospholipid syndrome, antiphospholipid antibodies, complement.

\section{INTRODUCTION}

The antiphospholipid syndrome (APS) is an autoimmune systemic disorder characterized by thrombosis and obstetric morbidity associated with persistent antiphospholipid antibodies (aPL) [1, 2]. Clinically, it causes venous and/or arterial thrombosis affecting blood vessels throughout the body, resulting in significant morbidity and occasionally mortality. The obstetric manifestations include three or more consecutive unexplained miscarriages, one or more unexplained death of a normal fetus at or beyond the $10^{\text {th }}$ week of gestation, evidence of placental insufficiency or one or more premature birth of a normal neonate before the $34^{\text {th }}$ week of gestation because of eclampsia or preeclampsia, or evidence of placental insufficiency [1] Serologically, the standard tests for APS are the lupus anticoagulant (LA), IgG and/or IgManticardiolipin (aCL) or IgG and/or IgManti- $\beta 2$ glycoprotein Iantibodies (anti- $\beta 2-\mathrm{GPI}$ ) which to diagnose the patient must be present on two or more consecutive occasions at least 12 weeks apart. The International consensus (revised Sapporo) classification criteria state that APS is present if at least one each of the clinical criteria and one of the laboratory criteria are met (Table 1) [1].

Additional clinical manifestations which are not included in the classificarion criteria (referred to as non-criteria manifestations) may be observed such as livedoreticularis, neurological manifestations, nephropathy, thrombocytopenia and heart valve disease even though they are not included in the classification criteria. The kidney is a major target organ in APS. However, it has not received much attention because of the common association between APS and systemic lupus erythematosus (SLE), which has historically, focused studies on immune-complex-mediated glomerulonephritis rather than renal vascular lesions [3]. There are many clinical

*Address correspondence to this author at the Centre for Rheumatology, UCL Division of Medicine, Room 424, Rayne Building, 5 University Street, WC1E 6JF, London, UK; Tel: 0203108 2148; Fax: 0203108 2152;

E-mail: d.isenberg@ucl.ac.uk presentations, due to both large vessels (arterial and venous) and microvasculature involvement (Table 2). Thrombotic microangiopathy is believed to be the characteristic nephropathy in APS [4]. The onset may be abrupt or insidious, with a wide range of severity. All vascular structures of the kidney can be affected including glomeruli, arterioles and parenchymatous arteries. Both acute and slowly progressive lesions heal with reparative fibrosis, with an increase in arterial hypertension evident in the chronic presentation [5]. Recently, the RITAPS study (a phase II study) assessed these non-criteria clinical manifestations (persistent thrombocytopenia, persistent autoimmune hemolyticanemia, cardiac valve disease, chronic skin ulcers, cognitive dysfunction or renal thrombotic microangiopathy). They selected and treated 19 aPL positive patients without a history of thrombosis or stroke with rituximab and foundit to be safe and probably effective in controlling some noncriteria manifestations of APS, such us cognitive dysfunction and skin ulcers [6].

Catastrophic APS (CAPS) is a rare, acute-onset condition that is characterized by sudden extensive microvascular thrombosis leading to multiorgan failure, most frequently affecting the kidneys (71\%), as well as the cardiorespiratory and central nervous systems [7]. CAPS may complicate established APS or present de novo. In an observational study of 1000 APS patients from 13 European countries spanning 10 years, CAPS occurred in $0.9 \%$ of patients, with a mortality rate of over $50 \%$ [2]. In those who survive, chronic renal failure is not uncommon. The pathogenesis of CAPS is not clearly understood, but episodes are often triggered by infections, surgery, or trauma, and widespread complement activation may play a role. Management is mainly based on case reports and usually comprises therapeutic anticoagulation in combination with immunonodulatory therapy including intravenous immunoglobulin, plasma exchange, corticosteroids, cyclophosphamide and rituximab, and ecululizumab (see below). 


\section{SEROLOGICAL CONSIDERATIONS}

APS is characterized by antibodies directed against protein epitopes combined to phospholipids; they do not bind directly to anionic phospholipids [8]. Antiphospolipid antibodies were first detected in sera from patients with syphilis, as the assay for the detection of this illness (VDRL, RPR) targets an antigen that contains cardiolipin [9]. The recognition that the real targets for the "so-called" phospholipid antibodies were protein co-factors, notably $\beta 2$ GPI, was a major step forward. We now distinguish between $\beta 2$-PI-dependent aCL antibodies that are correlated with thrombosis and fetal loss, and $\beta 2$-GPI-independent aCL antibodies that are not always present in APS, may be found in infections and seem to be more innocent [10]. Reports suggest that in genetically predisposed individuals, some infections can induce the formation of anti- $\beta 2$-GPI antibodies, and peptide epitopes of infectious agents can act as antigens and induce in mice aPL [8].

Anti- $\beta 2$-GPI antibodies can have lupus anticoagulant activity $[11,12]$. LA are antibodies directed against plasma proteins such as 32 -GPI, prothrombin, or annexin $\mathrm{V}$ that are bound to anionic phospholipids [13]. The detection of LA relies uponfunctional clotting tests. There are three reasons to call the term LA a misnomer. LA is associated with a thrombotic tendency rather than an anticoagulant effect and in fact, the anticoagulant is only an in vitro observation. Just about 50 percent of individuals with LA meet the American College of Rheumatology criteria for the classification of SLE, and there is more than one antibody associated with lupus anticoagulant activity. LA activity due to anti- $\beta 2$ glycoprotein Iantibodies correlates more strongly with thrombotic complications [14, 15] than LA caused by antiprothrombin antibodies. The presence of LA is a stronger risk factor for the development of thrombosis than are $\mathrm{aCL}$ oranti- $\beta 2$-GPI [16].

Antibodies against $\beta 2$-GPIare found in a large percentage of patients with APS [17]. They target a plasma protein, also known as apolipoprotein $\mathrm{H}$, which has unknown function. Despite many studies suggesting itis a lipopolysaccharide scavenger protein or complementregulator, several researchers suggest that lack ofß2-GPIis not associated with

\section{Table 1. Revised classification criteria for APS}

\section{APS is present if at least 1 of the clinical criteria and 1 of the laboratory criteria that follow are met ${ }^{\mathrm{a}}$ \\ Clinical criteria \\ 1. Vascular thrombosis \\ One or more clinical episodes ${ }^{\mathrm{c}}$, of arterial, venous, or small-vessel thrombosis ${ }^{\mathrm{d}}$ in any tissue or organ. Thrombosis must be confirmed by objective validated criteria (unequivocal findings of appropriate imaging studies or histopathology). For histopathological confirmation, thrombosis should be present without significant evidence of inflammation in the vessel wall. \\ 2. Pregnancy-related morbidity \\ (a) One or more unexplained deaths of a morphologically normal fetus at or beyond the 10th week of gestation, with normal fetal morphology documented by ultrasonography or by direct examination of the fetus, OR \\ (b) One or more premature births of a morphologically normal neonate before the 34th week of gestation because of (i) eclampsia or severe preeclampsia described according to standard definitions OR (ii) recognized features of placental insufficiency ${ }^{\mathrm{e}} \mathrm{OR}$ \\ (c) Three or more unexplained consecutive spontaneous abortions before the 10th week of gestation, with maternal anatomical or hormona abnormalities and paternal and maternal chromosomal causes excluded.}

\section{Laboratory criteria}

All laboratory criteria should be present on 2 or more occasions, at least 12 weeks apart.

1. LA present in plasma, detected according to the guidelines of the ISTH (Scientific Subcommittee on LAs/phospholipid-dependent antibodies).

2. aCL antibody of IgG and/or IgM isotype in serum or plasma, present in médium or high titer ( $>40 \mathrm{GPL}$ or MPL, or $>99^{\text {th }}$ of percentile), measured by standarized ELISA.

3. Anti-B2GP1 of IgG and/or IgM isotype in serum or plasma (in titer $>99$ th percentile), measured by a standardized ELISA, according to recommended procedures.

APS, antiphospholipid síndrome; LA, lupus anticoagulant; ISTH, International Society on Thrombosis and Haemostasis; aCL, anticardiolipin; GPL, IgG pgospsolipid; MPL, IgM phospholipid; ELISA; enzyme-linked immunosorbent assay; anti-B2GP1, anti-B2 glycoprotein-1; aPL, antiphospholipid antibodies; LDL, low-density lipoprotein; HDL, high-density lipoprotein; BMI, body mass index, GFR, glomerularfiltration rate.

${ }^{a}$ Classification of APS should be avoided if less 12 weeks or more than 5 years separate the positive aPL test resukt and the clinical manifestation-

${ }^{\mathrm{b}}$ Coexisting inherited or acquired factors for thrombosis are not reasons for excluding patients from APS trisld. However, 2 subgroups of patients with APS should be recognized, according to (a) the presence of any of the established risk factors for thrombosis. Such cases include age (>55 years in men and $>65$ years in women) and the presence of any of the established risk factors for cardiovascular disease; BMI $>30 \mathrm{~kg} / \mathrm{m}^{2} ;$ microalbuminuria; estimated GFR, $<60 \mathrm{Ml} / \mathrm{min} / 1.73 \mathrm{~m}^{2}$, inherited thrombophilias; oral contraceptives; nephrotic síndrome; malignancy; immobilization; and surgery. Thus, patients who fulfill criteria should be stratified according to contributing causes of thrombosis.

${ }^{\mathrm{c}}$ A thrombotic episode in the past could be considerer as a clinical criterion, provided tht thrombosis is proved by appropriate diagnostic means and that no alternative diagnosis or cause of thrombosis is found.

${ }^{\mathrm{d}}$ Superficial venous thrombosis is not included in the clinical criteria

${ }^{\mathrm{g}}$ Generally accepted features of placental insufficency include (i) abnormal or nonreassuring fetal fetal surveillance test(s), eg, a nonreactive nonstress test, suggestive of fetal hypoxemia; (ii) abdormal Doppler flow velocimetry waveform analysis suggestive of fetalhpoxemia, eg, absent end-diastolic flow in the umbilical artery; (iii) oligohydramnios, eg, an amniotic fluid index of $<5 \mathrm{~cm}$; $O R$ (iv) a postnatal birth weight $<$ the 10th percentile for the gestational age.

${ }^{\mathrm{f}}$ In the studies of populations of patients who have more than 1 type of pregnancy-related morbidity, investigators are strongly encouraged to stratify groups of subjects according to $\mathrm{a}, \mathrm{b}$, or $\mathrm{c}$ above.

${ }^{\mathrm{g}}$ Investigators are strongly advised to classify patients with APS into 1 of the following categories: I, more tan 1 laboratory criterion present (any combination); IIa, LA present alone; IIb, aCL antibody present alone; IIc, anti-B2GP1 antibody present alone 
any disease phenotype $[18,19]$ and can act as a naturally inhibitor of coagulation and platelet aggregation [7, 20]. This haemostasis inhibitor role of B2-GP-Icould explain why neutralizing antibodies promote thrombosis. It is known that among the population of B2-GPI antibodies, those specifically directed against an epitope on domain 1 of the protein are the most strongly associated with thrombosis [21].

Table 2. Clinical manifestations of renal involvement in APS.

\begin{tabular}{|c|c|}
\hline Vascular Lesion & Clinical Consequences \\
\hline \hline Renal artery lesions & $\begin{array}{c}\text { Arterial renovascularhypertension, } \\
\text { renal infarcts }\end{array}$ \\
\hline Glomerular capillarythrombosis & Tendency to renal insufficiency \\
\hline $\begin{array}{c}\text { Renal } \\
\text { thromboticmicroangiopathy }\end{array}$ & $\begin{array}{c}\text { Systemic hypertension and } \\
\text { renal failure }\end{array}$ \\
\hline Renal vein thrombosis & Renal failure \\
\hline
\end{tabular}

\section{CONSIDERING POSSIBLE MECHANISMS}

The pathophysiology of APS is incompletely understood. Although a prothrombotic basis is presumed, the thrombotic mechanisms are not well established in arterial and venous thrombosis. The obstetric problems are not due to thrombosis alone as thrombosis is neither a universal nor a specific feature in aPL-associated pregnancy loss, [22] and alternative mechanisms are emerging to explain aPL-associated pregnancy morbidity. Even less is known about the non-criteria manifestations, although as suggested by the RITAPS study, B cell depletion is probably effective [6].

A concept called "the two-hit theory" is used to explain the pathophysiology of some diseases. In the case of APS it implies that two triggersare needed to achieve the prothrombotic state. The first hit in the case of APS is likely to be the presence of aPL which have inflammatory and prothrombotic properties in endothelial, dendritic and mastocytic cells. The second would be an acute precipitating event such us surgery, infection, immobilization, pregnancy or oral contraceptives [7]. Autoantibodies from patients with APS potentiate thrombus formation when infused into mice with injured vessels. If the fraction of anti- $\beta 2-\mathrm{GPI}$ is removed, the clotting tendency disappears [23, 24].

Although many antibodieshave been involved in the pathogenesis of APS (including those binding toß2-GPI, prothrombin, annexin $\mathrm{A} 5$, protein $\mathrm{S}$, protein $\mathrm{C}$, factor $\mathrm{X} 1$, and factor XII), $[25,26] \beta 2$-glycoprotein seems to be the most relevant target [27]. This protein contains five homologous domains and can present in two different structural configurations. Domain $\mathrm{V}$ binds with negative charged phospholipids surfaces, whereas domain I binds antibodies. This first domain of $\beta 2-\mathrm{GPI}$ is identified to be the main epitope of the protein. Using domain-deletion mutants of the protein, Iverson et al. found that most anti- $\beta 2 \mathrm{GPI}$ antibodies reacted with domain I [27] There are several studies suggesting there is a clinical correlation between anti domain I anti- $\beta 2-G P I$ and clinical symptoms, both thrombosis and, interestingly, pregnancy morbidity [28] $\beta 2-$ GPI can be found in plasma in the closed circular configuration. This structure changes after interaction with anionic phospholipids (cardiolipin, apoptotic cells surfaces) to become an open linear configuration that exposes the previously hidden domain I epitope [29] and allows interaction with antibodies (Fig. 1). After the formation of the antigen-antibody inmunocomplex, the open linear configuration, also known as the "fishhook" remains open. The complex can activate cellular elements (monocytes, endothelial cells and platelets), inhibit the fibrinolytic system, activate the coagulation cascade, and the complement system [30]. Although the circular form has not been found in plasma, there is in vitro evidence of its presence. Administration of protein $\mathrm{H}$ (derived from $\mathrm{S}$ pyogenes) to mice has induced anti- $\beta 2-\mathrm{GPI}$ [31]. The chemical structure of $\beta 2-\mathrm{GPI}$ contains several disulfide bridges which link their domains between each other. In healthy individuals, these bridges are broken, the protein is less immunogenic, and is referred as the "free thiol form". APS patients also appear to have an increase in oxidative stress. Paroxonase activity, which prevents oxidation of low density lipoprotein cholesterol, is decreased; and [32, 33] 8 epi prostaglandin $\mathrm{F}$, which is a biomarker of lipid peroxidation, is raised [34]. Additionally, monocytes from APS patients have an increased amount of intracellular reactive oxygen species [35]. In these conditions, disulphide bonds are formedand $\beta 2-\mathrm{GPI}$, becomes more immunogenic [36]. Evidence exists that patients with APS have a greater proportion of the oxidized versus the "free thiol form" than do patients with either other autoimmune diseases but without APS, patients with thrombosis without aPL or healthy volunteers $(\mathrm{p}<0,001$ for all comparisons) [36]. In vitro studies showed that the "free thiol form" protects the endothelium from reactive oxygen species (ROS) [35] and that aPL promote formation of intracellular ROS. Furthermore, mice models studies suggest that ROS participate in the genesis of murine thrombosis [37]. Thus, drugs with an antioxidant effect might be helpful in the treatment of APS. There is evidence of Nacetylcysteineinhibition of ROS-mediated thrombosis [38] and coenzyme Q 10 inhibition of aPL mediated ROS generaration [39].

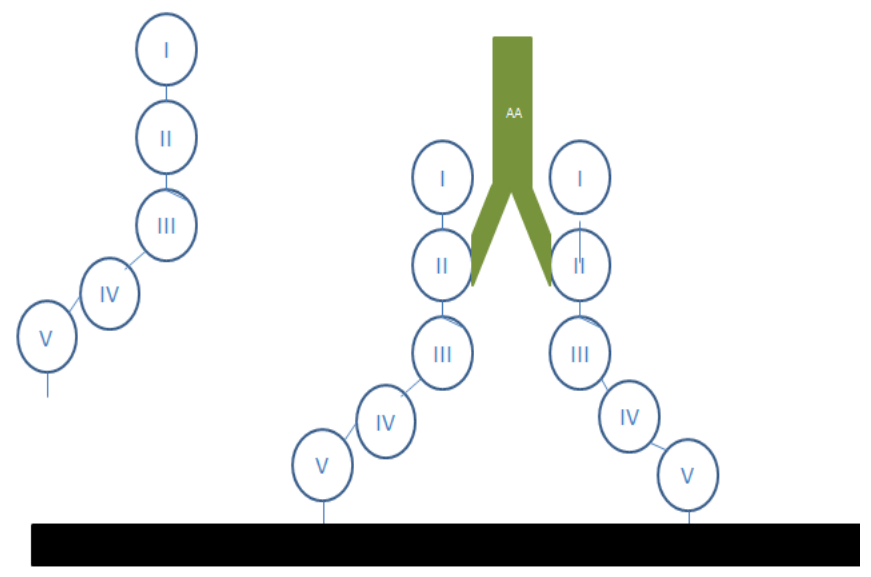

Fig. (1). $32-G P-I$ interactions with phospholipids and antibodies.

A possible mechanism of thrombosis is aPL-induced damage to the endothelial nitric oxide (eNO) synthesis pathway. APS patients have low plasma levels of eNO compared with controls [40] They also have an impaired, 


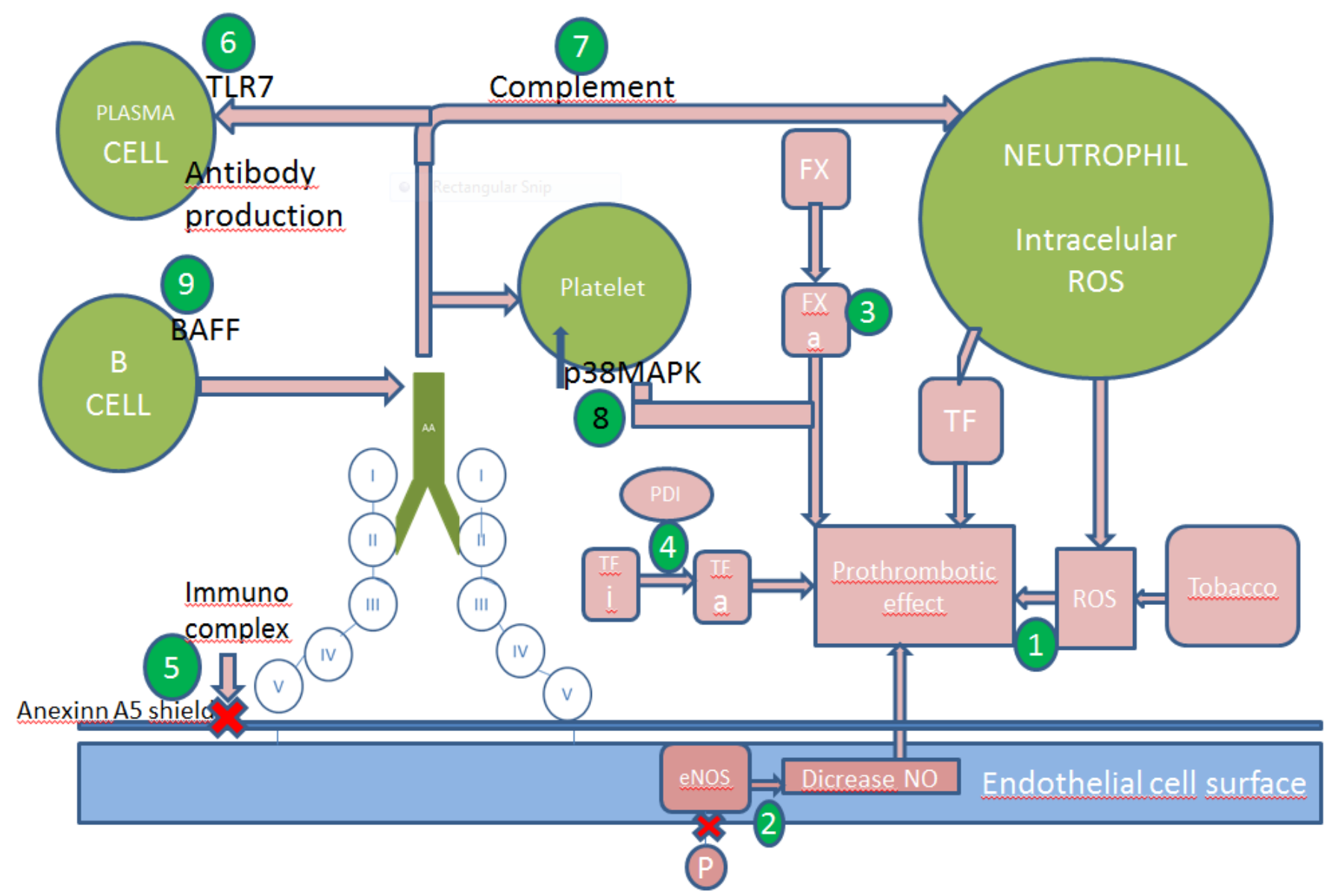

Fig. (2). Mechanisms of thrombosis and possible targets. Numbers indicates the sites of action of the following drugs: $1 \mathrm{~N}$-acetilcystein, 2 statins, 3 hydroxychloroquine, fluvastatin and FXa inhibitors(anticoagulants e.g. low molecular weight heparin, fondaparinux, rivaroxaban and edoxaban), 4 PDI inhibitors and hydroxychloroquine, 5hydroxychloroquine, 6 TLR7 inhibitors, 7 heparin, eculizumab, 8 belimumab.

vascular relaxation response due to NO [41]. Endothelial nitrite oxide is synthesized by the conversion of L-arginine by eNOS [42]. The impairment of enzyme activity leads to generation of superoxide and peroxynitrite [43]. In a murine model B2-GPI antibodies antagonize the activity of endothelial nitric oxide synthase (eNOS) which leads to low NO levels and monocyte adhesion to endothelial cells. Mice deficient in eNOS do not have this antiphospolipid-antibody thrombotic mechanism [44]. In vitro studies also showed HDL cholesterol dependent inhibition of eNOS in women with aPL [45]. Therefore, statins, which up regulate NOS activity, could be a logical treatment option as shown in vitro [46] and in an animal model [47].

Another target under scrutiny is tissue factor (TF). This factor is the key initiator of blood coagulation. After vessel injury, the TF: factor VIIa complex activates the coagulation protease cascade, which leads to fibrin deposition and activation of platelets. Tissue factor is located in an inactive form in the endothelial cell surface, and it needs phosphatidylserine to be exposed after a vessel injury, to be activated and to initiate coagulation. Tissue factor upregulation has been proposed as an important mechanism for development of a prothrombotic state in APS [48], Several studies suggest that patients with APS have increased levels of soluble TF and antibodies against TF pathway inhibitor (TFPI), suggesting impaired downregulation of TF [49, 50]. Further investigation is required to define TF pathway inhibitors. Tissue factor interaction with protein-disulfide isomerase (PDI), an extracellular regulator of thiol exchange, is also necessary to enable the prothrombotic role of this molecule [51]. Its expression is increased in patients with APS, and in vitro studies have demonstrated upregulation induced by antibodies on endothelial cells, neutrophils, monocytes. Potential thaeraputic modalities are PDI inhibitors, which attenuate murine thrombosis, and statins, which inhibit thrombosis in a murine model [52].

As explained above, aPL can upregulate the expression of procoagulant and proadhesive cell-surface molecules such as TF [52]. It is known that this effect is due to the interaction between B2-GPI antibodies between different receptors. Anti-B2-GPI target many different molecules on surface of cells. On endothelial cell surfaces, these antibodies bind proteins such as annexin A2, Toll Like Receptor 4 (TLR4), calreticulin and nucleolin to transfer intracellular signals. In monocytes, $32-\mathrm{GPI}$ is situated in the raft with annexin A2 and TLR4 [53-55]. Antibodies against B2-GPI stimulate them to produce TF and TNF alpha. The most relevant targets on platelets have been proposed to be the ApoE2 receptor [56] and glycoprotein Ibalpha [56, 57]. Further work is needed to define how antibodies penetrate into the cell [58] Once antibodies from patients with APS 
enter monocytes and endothelial cells, they can disrupt mitochondrial function, leading to the generation of ROS and the subsequent expression of TF [59]. Studies in animal models have demonstrated that annexin A2 knockout mice [60] and apoE receptor knockout mice [61] are protected from associated thrombosis with aPL. It is known that A1, an analogue of apoE R2 inhibits B2-GPI antibodies effects in vivo and in vitro $[62,63]$. Furthermore, treatment with NAC and coenzyme Q10 prevented the upregulation of TF related to presence of aPL [64]. A significant increase has been reported in the expression of GPIIb/IIIa on platelets treated with aPL antibodies and a thrombin receptor peptide agonist (TRAP). Treatment of platelets with aPL antibodies results in a significant increase in p38 mitogen-activated protein kinase (p38MAPK) phosphorylation, and aPL-induced platelet aggregation and thromboxane B2 (TXB2) production was abrogated by SB203580 (a p38MAPK inhibitor) [65].

Factor $\mathrm{X}$, is an enzyme of the final common pathway of the coagulation cascade which needs to be in its active form, FXa, to exert its procoagulant effect. In APS, FXa reactive IgG has higher avidity binding to $\mathrm{FXa}$, as well as a greater procoagulant effect, than in SLE patients without APS. FXasignalling is linked to interaction with protease-activated receptor (PAR) which leads to the release of intracellular calcium. Recently a study with 36 patients, including controls, characterized the interaction between $\mathrm{FXa}$ and human umbilical vein endothelial cells (HUVEC). An improvement was observed in FXa stimulation of HUVEC mediated via enhanced by FXa-reactive APS-IgG and a reduction of intracellular $\mathrm{Ca}^{2+}$ release in cells treated with a specific FXa inhibitor, HCQ and fluvastatin. These results suggest the important role of anti-FXaIgG predicting response to treatment with FXa inhibitors in APS [66].

APL appears to reduce annexinA5 levels and accelerate coagulation of plasma on cultured trophoblasts and endothelial cells. AnnexinA5 forms clusters that bind with high affinity to the surface of anionic phospholipids such as phosphatidylserine, and forms an anticoagulant shield made up of two-dimensional crystals that block phospholipids from availability for coagulation enzyme reactions. Antiphospholipid (aPL) antibodies cause gaps in the ordered crystallization of annexin A5, which expose phospholipids and thereby accelerate blood coagulation reactions. The reduction of annexinA5 levels on vascular cells may therefore be an important mechanisms leading to thrombosis and pregnancy loss in APS [67]. An ex vivostudy demonstratedthat plasmas with anti-32-GPI-dependent LAC that recognize domain I displayed significantly increased annexinA5 resistance. These observations suggest aPL may promote thrombosis by interfering with the anticoagulant activity of annexin A5 [68]. Endothelial cells exposed to aPL showed a decrease inannexin A5. The use of hydroxychloroquine (HCQ) is associated with inhibition of the annexin A5 shield in vivo, [69] and a decrease in thrombosis due to APS in mice [70].

Complement activation by aPL has recently been shown in mice models to play an important role in thrombosis, pregnancy loss and fetal growth restriction. APS mouse models demonstrate that passive transference of aPL from APS patients, to pregnant mice induce fetal loss and intrauterine growth restriction [71]. An association between thrombosis and complement in APS has also been demonstrated. Mice with and without C5 and C3 received both aPL and a vessel injury and only thrombi were formed in $\mathrm{C} 5+$ and $\mathrm{C} 3+$ mice. Complement is a complex system of plasma protein precursors. After a stimulus they become active and resulting in a stepwise cascade [72]. One of these proteins, C5, activated by aPL, leads toactivation of neutrophils and release of TF [73]. Thus, C5 and other complement proteins (C3) have been proposed as possible targets $[74,75]$. Reports document the use of eculizumab, a humanized $\mathrm{IgG}$ monoclonal antibody that inhibits $\mathrm{C5}$ cleavage and thereby generation of $\mathrm{C} 5 \mathrm{a}$ and $\mathrm{C} 3 \mathrm{~b}$, to treat catastrophic APS [76] and to prevent to prevent thrombosis after renal transplantation in patients with a history of CAPS [77]. In addition, an ongoing phase 2 study sponsored by Johns Hopkins University should be completed in 2015 (ClinicalTrials.gov Identifier: NCT01029587). Because heparin inhibits complement activation [78], mice treated with heparin after the injection of aPL do not develop fetal loss, unlike mice treated with the direct thrombin inhibitor, hirudin [79]. Some authors suggest that heparin prevents fetal loss through its effect on the complement pathway rather than an anticoagulant effect [80]. Although the current recommendations for APS patients are initial low molecular weight heparin (LMWH), LMWH has not been tested in patients with APS, and data from mice models are unclear [79].

Antiphospholipid syndrome occurs in $10-15 \%$ of patients with SLE although, 30-40\% have aCL [2]. In addition, approximately $35 \%$ of patients with SLE have LA [80] and ß2-GPI [81] antibodies respectively. In a mice model of SLE, the spontaneous development of domain 1 antibodies and analogous APS supported a relationship between the two syndromes and their pathogenesis [82]. Further investigations of this model suggested an important role for the translocation of the TLR7 gene, [83] with leads to increase antibody production [84], aPL can upregulate the expression of TLR7 on plasmocytoid dendritic cells [85]. Inhibition of TLR7 would be a potential target in patients with SLE and aPL.

$\mathrm{B}$ cell activating factor (BAFF) is a cytokine necessary for B cell survival which leads to development of an inhibiting antibody to target it [86]. Belimumab, which specifically targets BAFF, has recently been approved for SLE patients with joint and skin disease [87]. In a mice model, belimumab prevents thrombosis [88]. Thus, BAFF may be a potential target in the prevention of thrombosis in high risk patients with SLE.

Female/male ratios of autoimmune diseases invariably show a strong bias to female predisposition, [89] often in the childbearing years, reflecting a probable hormonal influence on their aetiology. Ben-Chetrit hypothesized that apparently healthywomen with "silent" illness might develop active disease because of repeated and prolonged exposure to estradioland gonadotropin [90]. Bruce and Laskin suggested thatacute hyperestrogenemia would be a risk to SLE patient. In a cohort of 1000 APS patients, Cerveraet all found a female/male ratio of $5: 1$. This ratio was higher in patients with SLE (7:1) than in primary APS $(3,5: 1)(\mathrm{p}<0,005)$ [91]. However, in an American retrospective studio with non-SLE associated APS in which patients received ovarian 
stimulation, there were no reports of thrombosis or maternal complications [92]. Studies to improve knowledge of hormonal influence are in progress.

It is becoming increasingly clear that the concurrence of environmental factors with genetic abnormalities or genetic predisposition, determines whether and when a person will develop APS [93]. Several studies suggest an increased risk of venous thromboembolism(VTE) linked to the presence of heritable thrombophilic defects with aPL. In a Dutch study, Factor V Leiden and the G20210A prothrombin mutation were shown to contribute to the risk of VTE in patients with SLE, with the risk potentiated when one of these thrombophilic defects occurred in combination with LA and/or aCL [94]. Many other studies have implicated genetic factors. In a series of 23 patients with aCL, 29 of their 87 relatives (33\%) also had aCL [95]. In Canadian, German, Italian, and Mexican patients an association of aPL with HLA-DR7 has been observed, and in American and Spanish patients, with HLA-DQ [96]. In a large Swedish cohort of patients with SLE, the expression of various aPL was associated with HLA-DRB1 04 and HLA-DRB1 13. These alleles were also found to be more frequent among patients with cerebral stroke and with any vascular event (venous thromboembolism, ischemic heart disease and cerebral stroke), respectively [97]. Certain polymorphisms of the B2GPI gene and of the HLA-DMA and HLA-DMB genes may also enhance the risk of development aPL antibodies after been inherited [98], Further investigations are needed to understand the genetic predisposition to develop APS.

\section{CONCLUSION}

In conclusion, it is evident that a variety of mechanisms may act independently, or in conjunction, to lead to the clinical features associated with APS. The challenge is to determine, which of these are the key mechanisms in APS associated with venous and/or arterial thrombosis, and pregnancy loss, as well as the key mechanisms in the noncriteria manifestations of APS.

\section{CONFLICT OF INTEREST}

The authors confirm that this article content has no conflict of interest.

\section{ACKNOWLEDGEMENTS}

Declared none.

\section{REFERENCES}

[1] Miyakis S, Lockshin MD, Atsumi T, et al. International consensus statement on an update of the classification criteria for definite antiphospholipid syndrome (APS). J Thromb Haemost 2006; 4: 295-306.

[2] Cervera R1, Serrano R, Pons-Estel GJ, et al. Morbidity and mortality in the antiphospholipid syndrome during 10-year period: a multicentre prospective study of 1000 patients. Arthritis Rheum 2014; doi: 10.1136/annrheumdis-2013-204838.

[3] Piette JC, Cacoub P, Wechsler B. Renal manifestations of the antiphospolipid syndrome. Semin Arthritis Rheum 1994; 23: 35766.

[4] Nochy D, Daugas E, Droz D, et al. The intrarenal vascular lesions associated with primary antiphospholipid syndrome. J Am Soc Nephrolo 1999; 10: 507-18.
[5] Lacueva J, Enriquez R. Acute renal failure as first clinical manifestation of the primary antiphospholipid syndrome. Nephron 1993; 64: 479-80.

[6] Erkan D, Vega J, Ramon G, Kozora E, Lockshin MD. A pilot open-label phase II trial of rituximab for non-criteria manifestations of antiphospholipid syndrome. Arthritis and Rheumatism 2013; 65: 464-71.

[7] Cervera R, Espinosa G. Update on the catastrophic antiphospholipid syndrome and the "CAPS Registry" Semin Thromb Hemost 2012; 38(4): 333-8.

[8] Passam F, Krilis S. Laboratory tests for the antiphospholipid syndrome: current concepts. Pathology 2004; 36:129.

[9] de Groot PG, Derksen R. The antiphospholipid syndrome: clinical characteristics, laboratory features and pathogenesis. Curr Opin Infect Dis 2005; 18: 205-10.

[10] Chamley LW, McKay EJ, Pattison NS. Cofactordependent and cofactor independent anticardiolipin antibodies. Thromb Res 1991; 61(3): 291-9.

[11] Oosting JD, Derksen RH, Entjes HT, Bouma BN, de Groot PG. Lupus anticoagulant activity is frequently dependent on the presence of beta2-glycoprotein I. Thromb Haemost 1992; 67(5): 499-502.

[12] Roubey RA, Pratt CW, Buyon JP, Winfield JB.Lupus anticoagulant activity of autoimmune anti phospholipid antibodies is dependent upon beta 2-glycoprotein I. J Clin Invest 1992; 90: 1100-4.

[13] Meroni PL, Borghi MO, Raschi E, Tedesco F. Pathogenesis of antiphospholipid syndrome: understanding the antibodies. Nat Rev Rheumatol 2011; 7: 330-9.

[14] Zwaal RF. Lupus anticoagulant IgG's (LA) are not directed to phospholipids only, but to a complex of lipid-bound human prothrombin. Thromb Haemost 1991; 66: 629-32.

[15] de Laat B, Derksen RH, Urbanus RT, de Groot PG. IgG antibodies that recognize epitope Gly40-Arg43 in domain I of beta 2glycoprotein I causeLAC, and their presence correlates strongly withthrombosis. Blood 2005; 105: 1540-5.

[16] Calli M, Luciani D, Berbolini G, et al. Anti-ß2-glicoproteine, antitrombine antibodies and the risk of thrombosis in the APS. Blood 2003; 102(8): 2717-23.

[17] Day HM, Thiagarajan P, Ahn C, et al. Autoantibodies to $\beta-2-$ glycoprotein I in systemic lupus erythematosus and primary antiphospholipid antibody syndrome: clinical correlations in comparison with other antiphospholipid antibody tests. J Rheumatol 1998; 25: 667-74.

[18] Agar C, de Groot PG, Marquart JA, Meijers JC. Evolutionary conservation ofthe lipopolysaccharide binding site of $\beta-2$ glycoprotein I. Thromb Haemost 2011; 106: 1069-75.

[19] Gropp K, Weber N, Reuter M, et al. $\beta$-2-glycoprotein I, the major target in antiphospholipid syndrome, is a special human complement regulator. Blood 2011; 118: 2774-83.

[20] Harris EN, Gharavi A, Asherson RA, et al. Antiphospholipid antibodies-middle aged but robust. J Rheumatol 1994; $21: 978$.

[21] Ioannou Y, Pericleous C, Giles I, Latchman DS, Isenberg DA, Rahman A. Binding of antiphospholipid antibodies to discontinuosus epitopes od domain I of human beta(2)-GP 1: mutation studies including residues R 39 to R43. Arthritis Rheum 2007; 56: 280-90.

[22] Out HJ, Kooijman CD, Bruinse HW, Derksen RH. Histopathological findings in placentae from patients with intrauterine fetal death and anti-phospholipid antibodies. Eur J Obstet Gynecol Reprod Biol 1991; 41:179-86.

[23] Fischetti F, Durigutto $\mathrm{P}$, Pellis $\mathrm{V}$, et al. Thrombus formation induced by antibodies to $\beta$-2-glycoprotein $\mathrm{I}$ is complement dependent and requires a priming factor.Blood 2005;106:2340-6.

[24] Arad A, Proulle V, Furie RA, Furie BC, Furie B. $\beta(2)$-glycoprtein1 autoantibodies from patients with antiphospholipid syndrome are sufficient to potentiate arterial thrombus formation in a mouse model. Blood 2011; 117: 3453-9.

[25] Yoon KH, Wong A, Shakespeare T, et al. High prevalence of antiphospholipid antibodies in Asian cancer patients with thrombosis. Lupus 2003; 12: 112-6.

[26] Font C, Vidal L, Espisona G, et al. Solid cancer, antiphospholipid antibodies, and venous thromboembolism. Autoimmun Rev 2011; 10: 222-7.

[27] Matsuura E, Shen L, Matsunami Y, et al. Pathophysiology of beta2-glycoprotein I in antiphospholipid syndrome. Lupus 2010, 19: 379-84. 
[28] Iverson GM, Victoria EJ, Marquis DM. Anti-beta2 glycoprotein I (beta2GPI) autoantibodies recognize an epitope on the first domain of beta2GPI. Proc Natl Acad Sci USA1998, 95:15542-6.

[29] Atsumi T, Tsutsumi O. Correlation between beta2GPIvaline/ leucine ${ }^{247}$ polymorphism and anti beta2GI antibodies in patients with primary APS. Rheumatology 1999; 38: 721-3.

[30] Lim W. Complement and the antiphospholipid syndrome. Current Opinion in Hematology 2011; 18: 361-5.

[31] Van Os GM, Meijers JC, Agar C, et al. Induction of anti- $\beta 2-$ glycoprotein I autoantibodies in mice by protein $\mathrm{H}$ of Streptococcus pyogenes. J Thromb Haemost 2011; 9: 2447-56.

[32] Delgado-Alves J, Ames PR, Donohue S, et al. Antibodies to highdensity lipoprotein and beta2-glycoprotein I are inversely correlated with paraoxonase activity in systemic lupus erythematosus and primary antiphospholipid syndrome. Arthritis Rheum 2002; 46: 2686-94.

[33] Charakida M, Besler C, Batuca JR, et al. Vascular abnormalities, paraoxonase activity, and dysfunctional HDL in primary antiphospholipid syndrome. JAMA 2009; 302:1210-7.

[34] Ames PR, Nourooz-Zadeh J, Tommasino C, Alves J, Brancaccio V, Anggard EE. Oxidative stress in primary antiphospholipid syndrome. Thromb Haemost 1998; 79: 447-9.

[35] Perez-Sanchez C, Ruiz-Limon P, Aguirre MA, et al. Mitochondrial dysfunction in antiphospholipid syndrome: implications in the pathogenesis of the disease and effects of coenzyme $Q(10)$ treatment. Blood 2012; 119: 5859-70.

[36] Ioannou Y, Zhang JY, Qi M, et al. Novel assays of thrombogenic pathogenicity for the antiphospholipid syndrome based on the detection of molecular oxidative modification of the major autoantigen $\beta 2$-glycoprotein I. Arthritis Rheum 2011; 63: 2774-82.

[37] Nishimura $\mathrm{S}$, Manabe I, Nagasaki $\mathrm{M}$, et al. In vivo imaging visualizes discoid platelet aggregations without endothelium disruption and implicates contribution of inflammatory cytokine and integrin signaling. Blood 2012; 119: 45-56.

[38] Ruiz-Irastorza G, Crowther M, Branch W, Khamashta MA. Antiphospholipid syndrome. Lancet 2010; 376:1498-509.

[39] Perez-Sanchez C, Ruiz-Limon P, Aguirre MA, et al. Mitochondrial dysfunction in antiphospholipid syndrome: implications in the pathogenesis of the disease and effects of coenzyme Q(10) treatment. Blood 2012; 119: 5859-70.

[40] Ames PR, Batuca JR, Ciampa A, Iannaccone L, Delgado Alves J. Clinical relevance of nitric oxide metabolites and nitrativestress in thrombotic primary anti phospholipid syndrome. J Rheumatol 2010; 37: 2523-30.

[41] Charakida M, Besler C, Batuca JR, et al. Vascular abnormalities, paraoxonaseactivity, and dysfunctional HDL in primary anti phospholipid syndrome. JAMA 2009; 302: 1210-7.

[42] Palmer RM, Ashton DS, Moncada S. Vascular endothelial cells synthesize nitric oxide from L-arginine. Nature 1988; 333: 664-6.

[43] Beckman JS, Beckman TW, Chen J, Marshall PA, Freeman BA. Apparent hydroxyl radical production by peroxynitrite: implications for endothelial injury from nitricoxide and superoxide. Proc Natl Acad Sci USA 1990; 87: 1620-4.

[44] Ramesh S, Morrell CN, Tarango C, et al. Antiphospholipid antibodies promote leukocyte-endothelial cell adhesion andthrombosis in mice by antagonizing NOS via $\beta 2 \mathrm{GPI}$ and apoER2. J Clin Invest 2011; 121: 120-31.

[45] Charakida M, Besler C, Batuca JR, et al. Vascular abnormalities, paraoxonase activity, and dysfunctional $\mathrm{HDL}$ in primary antiphospholipid syndrome. JAMA 2009; 302: 1210-7.

[46] Laufs U, La Fata V, Plutzky J, Liao JK. Upregulation of endothelial nitric oxide synthase by HMG CoA reductase inhibitors. Circulation 1998; 97: 1129-35.

[47] Ferrara DE, Liu X, Espinola RG, et al. Inhibition of the thrombogenic and inflammatory properties of antiphospholipid antibodies by fluvastatin in an in vivo animal model. Arthritis Rheum 2003; 48: 3272-9.

[48] Oku K, Amengual O, Atsumi T. Pathophysiology of thrombosis and pregnancy morbidity in the antiphospholipid syndrome. Eur $\mathrm{J}$ Clin Invest 2012; 42:1126-35.

[49] Forastiero RR, Martinuzzo ME, de Larrañaga GF. Circulating levels of tissue factor and proinflammatory cytokines in patients with primary antiphospholipid syndrome or leprosy related antiphospholipid antibodies. Lupus 2005; 14:129-36.

[50] Forastiero RR, Martinuzzo ME, Broze GJ. High titers of autoantibodies to tissue factor pathway inhibitor are associated with the antiphospholipid syndrome. J Thromb Haemost $2003 ; 1$ : 71824.

[51] Versteeg HH, Ruf W. Thiol pathways in the regulation of tissue factor prothrombotic activity. Curr Opin Hematol 2011;18: 343-8.

[52] Ritis K, Doumas M, Mastellos D, et al. A novel C5a receptor-tissue factor cross talk in neutrophils links innate immunity to coagulation pathways. J Immunol, 2006; 177: 4794-802.

[53] Ma K, Simantov R, Zhang JC, Silverstein R, Hajjar KA, McCrae KR. High affinity binding of $\beta$-2-glycoprotein I to human endothelial cells is mediated by annexin II. J BiolChem 2000; 275:15541-8.

[54] Allen KL, Fonseca FV, Betapudi V, Willard B, Zhang J, McCrae KR. A novel pathway for human endothelial cell activation by antiphospholipid/anti- $\beta 2$ glycoprotein I antibodies. Blood 2012; 119: 884-93.

[55] Raschi E, Testoni C, Bosisio D, et al. Role of the MyD88 transduction signaling pathway in endothelial activation by antiphospholipid antibodies. Blood 2003; 101: 3495-500.

[56] Urbanus RT, Pennings MT, Derksen RH, de Groot PG. Platelet activation by dimeric $\beta$-2-glycoprotein I requires signaling via both glycoprotein I alpha and a polipoprotein E receptor $2^{\prime}$. J Thromb Haemost 2008; 6:1405-12.

[57] Shi T, Giannakopoulos B, Yan X, et al. Anti-beta2-glycoprotein I antibodies incomplex with beta2-glycoprotein I can activate platelets in a dysregulated manner via glycoprotein Ib-IX-V. Arthritis Rheum 2006; 54: 2558-67.

[58] Satta N, Kruithof EK, Fickentscher C, et al. Toll-like receptor 2 mediates the activation of human monocytes and endothelial cells by antiphospholipid antibodies. Blood 2011; 117: 5523-31.

[59] Perez-Sanchez C, Ruiz-Limon P, Aguirre MA, et al. Mitochondrial dysfunction in antiphospholip id syndrome: implications in the pathogenesis of the disease and effects of coenzyme Q(10) treatment. Blood 2012; 119: 5859-70.

[60] Ramesh S, Morrell CN, Tarango C, et al. Antiphospholipid antibodies promote leukocyte-endothelial cell adhesion and thrombosis in mice by antagonizing eNOS via $\beta 2 \mathrm{GPI}$ and apoER2. J Clin Invest 2011; 121:120-31.

[61] Romay-Penabad Z, Montiel-Manzano MG, Shilagard T, et al Annexin A2 is involved in antiphospholipid antibody mediated pathogenic effects in vitro and in vivo. Blood 2009; 114: 3074-83.

[62] Romay-Penabad Z, Aguilar-Valenzuela R, Urbanus RT, et al. Apolipoprotein E receptor 2 is involved in the thrombotic complications in a murine model of the antiphospholipid syndrome. Blood 2011; 117:1408-14.

[63] Ioannou Y, Romay-Penabad Z, Pericleous $\mathrm{C}$, et al. In vivo inhibition of antiphospholipid antibody-induced pathogenicity utilizing the antigenic target peptide domain I of $\beta$-2-glycoprotein I: proof of concept. J Thromb Haemost 2009; 7: 833-42.

[64] Perez-Sanchez C, Ruiz-Limon P, Aguirre MA, et al. Mitochondrial dysfunction in antiphospholipid syndrome: implications in the pathogenesis of the disease and effects of coenzyme Q(10) treatment. Blood 2012; 119: 5859-70.

[65] Pierangeli SS1, Vega-Ostertag M, Harris EN. Intracellular signaling triggered by antiphospholipid antibodies in platelets and endothelial cells: a pathway to targeted therapies. Thromb Res 2004; 114(5-6): 467-76.

[66] Artim-Esen B, Smoktunowicz N, Isenberg D, Rahman A, Giles I. The cellular effects of anti-factor $\mathrm{Xa}$ antibodies isolated from patients with APS are inhibited by factor Xa inhibitors, HCQ and fluvastatin. Rheumatology 2014, 53: 55-6.

[67] Rand JH1, Wu XX, Quinn AS, Taatjes DJ. The annexin A5mediated pathogenic mechanism in the antiphospholipid syndrome: role in pregnancy losses and thrombosis. Lupus 2010 ; 19(4): 4609.

[68] de Laat B, Wu XX, van Lummel M, Derksen RH, de Groot PG, Rand $\mathrm{JH}$. Correlation between antiphospholipid antibodies that recognize domain I of $\beta$-2-glycoprotein I and a reduction in the anticoagulant activity of annexin A5. Blood 2007; 109: 1490-4.

[69] Rand JH, Wu XX, Quinn AS, et al. Hydroxychloroquine protects the annexin A5 anticoagulant shield from disruption by antiphospholipid antibodies: evidence for a novel effect for an old antimalarial drug. Blood 2010; 115: 2292-9.

[70] Edwards MH, Pierangeli S, Liu X, Barker H, Anderson G, Harris EN. Hydroxychloroquine reverses thrombogenic properties of antiphospholipid antibodies in mice. Circulation 1997; 96: 4380-4. 
[71] Pierangeli SS, Colden-Stanfield M, Liu X, Barker JH, Anderson GL, Harris EN. Antiphospholipid antibodies from antiphospholipid syndrome patients activate endothelial cells in vitro and in vivo. Circulation 1999; 99: 1997-2002.

[72] Chen XX, Gu YY, Li SJ, et al. Some plasmin-induced antibodies bind to cardiolipin, display lupusanticoagulant activity and induce fetal loss in mice. J Immunol 2007; 178 : 5351-6.

[73] Ritis K, Doumas M, Mastellos D, et al. A novel C5a receptor-tissue factor crosstalk in neutrophils links innate immunity to coagulation pathways. J Immunol 2006; 177: 4794-802.

[74] Holers VM, Girardi G, Mo L, et al. Complement C3 activation is required forantiphospholipid antibody-induced fetal loss. J Exp Med 2002; 195: 211-20.

[75] Girardi G, Berman J, Redecha P, et al. Complement C5a receptors and neutrophils mediate fetal injury in the antiphospholipid syndrome. J Clin Invest 2004;113: 646.

[76] Shapira I, Andrade D, Allen SL, Salmon JE. Brief report: induction of sustained remission in recurrent catastrophic antiphospholipid syndrome via inhibition ofterminal complement with eculizumab. Arthritis Rheum 2012; 64: 2719-23.

[77] Lonze BE, Singer AL, Montgomery RA. Eculizumab and renal transplantation ina patient with CAPS. N Engl J Med 2010; 362:1744-5.

[78] Dobado-Berrios PM, Lopez-Pedrera C, Velasco F, Aguirre MA, Torres A, Cuadrado MJ. Increased levels of tissue factor mRNA inmononuclear blood cells of patients with primary antiphospholipid syndrome. Thromb Haemost 1999; 82 :1578-82.

[79] Reverter JC, Tassies D, Font J, et al. Effects of human monoclonal anticardiolipin antibodies onplatelet function and on tissue factor expression on monocytes. Arthritis Rheum1998; 41:1420-7.

[80] Ioannou Y, Zhang JY, Passam FH, et al. Naturally occurring free thiols within $\beta$-2-glycoprotein I in vivo: nitrosylation, redox modification by endothelial cells, and regulation of oxidative stress-induced cell injury. Blood 2010; 116: 1961-70.

[81] Bruce IN, Clark-Soloninka CA, Spitzer KA, Gladman DD, Urowitz MB, Laskin CA. Prevalence of antibodies to $\beta$-2-glycoprotein I in systemic lupus erythematosus and their association with antiphospholipid antibody syndrome criteria: a single center study and literature review. J Rheumatol 2000; 27: 2833-7.

[82] Reddel SW, Wang YX, Sheng YH, Krilis SA. Epitope studies with anti- $\beta$-2-glycoprotein I antibodies from autoantibody and immunized sources. J Autoimmun 2000; 15: 91-6.

[83] Pisitkun P, Deane JA, Difilippantonio MJ, Tarasenko T, Satterthwaite AB, Bolland S. Autoreactive B cell responses to RNA-related antigensdue to TLR7 gene duplication. Science 2006; 312:1669-72.
[84] Christensen SR, Shupe J, Nickerson K, Kashgarian M, Flavell RA, Shlomchik MJ. Toll-like receptor 7 and TLR9 dictate autoantibody specificity and have opposing inflammatory and regulatory roles in a murine model of lupus. Immunity 2006; 25: 417-28.

[85] Prinz N, Clemens N, Strand D, et al. Anti phospholipid antibodies induce translocation of TLR7 and TLR8 to the endosome in human monocytes and plasmacytoid dendritic cells. Blood 2011; 118: 2322-32.

[86] Mackay F, Schneider P. Cracking the BAFF code. Nat Rev Immunol 2009; 9: 491-502.

[87] Fairfax K, Mackay IR, Mackay F. BAFF/BLyS inhibitors: a new prospect fortreatment of systemic lupus erythematosus. IUBMB Life 2012; 64: 595-602.

[88] Kahn P, Ramanujam M, Bethunaickan R, et al. Prevention of murine anti phospholipid syndrome by BAFF blockade. Arthritis Rheum 2008; 58: 2824-34.

[89] Lockshin MD, Volcker B, Kirkland M. Sex differences in autoimmune disease. Lupus 2006; 15:753-6.

[90] Ben-Chetrit A, Ben-Chetrit E. Systemic lupus erythematosus induced by ovulation induction treatment. Arthritis Rheum 1994; 37: 1614-7.

[91] Cervera R, Font J. Antiphospolypid syndrome. Clinical and immunological manifestions and patterns of disease expression in a cohort of 1.000 patients. Arthritis Rheumat 2002; 46: 1019-27.

[92] Guballa N, Ovulation induction and in vitro fertilization in systemic lupus erythematosus and antiphospholipid syndrome. Arthritis Rheum 2000; 43: 550-6

[93] Castro-Marrero J. Genetic risk factors of thrombosis in the antiphospholipid syndrome. Br J Haematol 2009; 147: 289-96

[94] Nojima J, Kuratsune H, Suehisa E, et al. Acquired activated protein $\mathrm{C}$ resistance is associated with the co-existence of anti-prothrombin antibodies and lupus anticoagulant activity in patients with systemic lupus erythematosus. Br J Haematol 2002; 118: 577.

[95] Goldberg SN, Conti-Kelly AM, Greco TP. A family study of anticardiolipin antibodies and associated clinical conditions. Am J Med 1995; 99: 473.

[96] Schur PH. Genetics of systemic lupus erythematosus. Lupus 1995; 4:425.

[97] Lundström E, Gustafsson JT, Jönsen A, et al. HLA-DRB1*04/*13 alleles are associated with vascular disease and antiphospholipid antibodies in systemic lupus erythematosus. Ann Rheum Dis 2013; 72:1018-1025.

[98] Hirose N, Williams R, Alberts AR, et al. A role for the polymorphism at position 247 of the beta2-glycoprotein I gene in the generation of antibeta2glycoprotein antibodies in the antiphospholipid syndrome. Arthitis Rheum 1999; 42:1655-61.

This is an open access article licensed under the terms of the Creative Commons Attribution Non-Commercial License (http://creativecommons.org/licenses/by-nc/3.0/) which permits unrestricted, non-commercial use, distribution and reproduction in any medium, provided the work is properly cited. 